\title{
RIGHTS, DEMOCRACY AND DEVELOPMENT: THE JUDICIALSYSTEM'S ROLE IN DEVELOPING COUNTRIES
}

Vivian Maria Pereira Ferreira

Lawyer, Master of Law / FGV Direito SP.

vivianmpferreira@gmail.com

Natalia Langenegger

Lawyer; Master of Law / FGV Direito SP.

natalia.langenegger@gmail.com

\begin{abstract}
This article seeks to discuss whether and how the judicial system has been assuming a new institutional role in the design of public policies aimed at promoting of Economical Social and Cultural Rights (ESCR) in developing countries. Considering that these rights are crucial for human and social development, the article discusses the ways in which the judicial system might interfere with the process of development.

Alongside a theoretical debate, the article presents a functionalist comparative study of the public interest litigation in Brazil, India and South Africa. It focuses on how judges seek to promote ESCR as well as on the benefits and problems of their intervention in public policies created by democratic governments and legislatures.

The diagnosis that judicial systems around the world play different roles from the ones recommended by the economic neoliberal mainstream shows that several different institutional arrangements are possible and that some of them might be more adequate to the reality of the developing world. Therefore, the article hopes to provide insights to rethink global governance and the current knowledge on law and political economy from a new paradigm.
\end{abstract}

Keywords: Judicial System - Economical Social and Cultural Rights Public Policy - Development - Democracy 


\section{INTRODUCTION}

During the 1990s, in the context of a recovery of the liberal thought, economic mainstream was based upon the notion that economic development depended on the enactment of laws which would assure predictability to economical transactions. Law should, therefore, guarantee property rights and the enforcement of contracts. By properly applying legal rules and dictating the rules of the economic game, institutions were deemed responsible for reducing transaction costs and uncertainty. ${ }^{1}$

This institutionalist approach fostered international efforts to promote institutional reforms in developing countries. The World Bank, for instance, promoted a package of reforms which prescribed a set of specific economic policies which should be implemented in developing countries. Reforms were made in a "one size fits all" fashion, as if policies that had promoted economic growth in developed countries should also impel developing countries ${ }^{2}$ to finally develop. One of the major focuses of institutional reform was the judicial system, which was considered essential for the protection of property rights and for assuring the predictability needed in order to sustain continued economic growth.

This formal and allegedly neutral role assigned to the judicial system by the neoliberal mainstream, however, does not correspond to the current role played by Courts in many developing countries. In some countries, such as Brazil, it is clear that Courts have started to act in a more pro-active way, taking the initiative to design public policies and to decide about complex and polycentric issues involving the allocation of scarce resources. ${ }^{3}$

In fact, the historical recognition of human and fundamental rights has led to significant changes in the juridical culture, with the inclusion of economic, social and cultural rights (ESCR) in the constitutions of countries worldwide. These changes have also reached the developing world, where States were financially and structurally incapable of actually enforcing those rights. This tragic combination of constitutional promises of ESCR and States that are not capable of enforcing them has led civil society to seek the effectiveness of their rights $^{4}$ in the judicial system.

Therefore, the main objective of this article will be to discuss whether and how the judicial system has been assuming a new role in developing countries as an important institution in the designing of

1 TRUBEK, (2012)

2 PISTOR \& MILHAULPT (2008)

3 TAYLOR (2008)

4 LIMA LOPES (2006), pp. 190-191; VERÍSSIMO (2006), pp. 67-68. 
public policies regarding the promotion of ESCR. Considering that these rights are absolutely fundamental for achieving human and social development, ultimately the article addresses the question of whether and how the judicial system can be a key institution to intervene towards achieving development.

The article is divided in five sections. The first section is aimed at contextualizing the different roles assigned to the judicial system in the different moments of developmental history. The second section will explain the concept of development adopted in the article and why good democratic institutions are essential for achieving it. The third section will argue that the judiciary assumes a relevant position in achieving development because it grants individuals means through which they may hold accountable those who are dully fulfilling governmental representation. In the fourth section a comparative study will be developed with the aim of identifying similarities and differences in judicial adjudication of ESCR undertaken in Brazil, India and South Africa. Finally, the last chapter of the article will conclude affirming that, should ECSR be object of litigation, the solution must be built jointly by the Courts, the government's representatives and society.

This article represents an effort to move beyond the Brazilian case and to foster policy debates amongst developing and developed countries about the important role the judicial system might play in the developmental process. In the context of the emergence of a new state activism, different institutional means to achieve development must be identified, analyzed and compared in its successes and failures.

In fact, the existence of an alternative institutional arrangement to the judicial system, different from that recommended by the economic neoliberal mainstream, demonstrates that there may be different arrangements, more adequate to the reality of the developing world.

\section{THE DIFFERENT ROLES ASSIGNED TO THE JUDICIAL SYSTEM}

The judicial system may be defined as the governmental branch responsible for enforcing the law, interpreting and adapting it to concrete cases and solving disputes and conflicts. Although quite appropriate, this definition may suggest that judges and Courts have been playing one single role in society ever since their creation - what could not be more deceiving.

It is important to notice that many different roles have been assigned to the judicial system, according to the different types of functions it was considered able to fulfill in the construction of a specific kind of society. In different times and places, ideologies and politics were responsible for the shifts in the way judges and Courts operated. As one key institution of the modern state, the judicial system cannot be 
disregarded when it comes to the discussions about development.

In fact, studies on the phenomenon of development did not always regard judicial system as a central concern, sometimes looking at it as more of an accessory. It is nevertheless possible to identify the different legal theories often implicit in the various economical and political projects of mainstream development professionals, ${ }^{5}$ and consequently the different roles assigned to the judicial system in each one of them.

In this sense, following Trubek and Santos ${ }^{6}$, it is possible to identify three different moments in the history of the relation between law and development: (i) the classic developmentalism (1950-1980); (ii) the neoliberal reaction (1980-1995); and (iii) the new developmental state (1995-the present).

During the first moment, the classic developmentalism, States were the main economic driver, responsible for inducing social transformations and for changing and channeling economic behavior. Policies were implemented in order to promote industrialization, to stimulate the blooming of internal economic market and to direct resources to strategic areas. States sought to create national plans, reallocate resources, invest and manage key sectors and control foreign capital.

In this moment, law was seen in an instrumental fashion, as a tool to support state's policies and to generate economic growth. In this sense, law had distributional purposes: it was aimed at allocating resources among social and economical groups in order to implement national economic policy objectives.

Therefore, Public and Administrative Law gained importance, allowing the creation of a powerful state bureaucracy - employed by the Executive and Legislative branches in the regulation of economy and in the definition of national economic policies. This was done quite freely, sometimes even affecting private rights, and without judicial review since in that period, as Kennedy puts it, "the judicial assertion of rights against postwar development policies was by and large a nonproblem".

During the 1970s, developmental states started to show signs of extenuation. In spite of all efforts, most Latin America, East Europe and Asia countries were still underdeveloped. The US legal elite interpreted this phenomenon as a result from a series of cultural and institutional resistances that prevented legal professionals from adopting a more pragmatic and antiformalist attitude towards law. According to that understanding, efforts were made to build a more pragmatic local

5 The idea according to which it is possible to "reverse engineer the legal theory of mainstream development professionals from their economic and political projects" is here taken from KENNEDY (2006), p. 102.

6 TRUBEK \& SANTOS (2006)

7 KENNEDY (2006), p. 104. 
legal culture in developing countries. The reforming agenda focused on legal education and emphasized the need for law professionals including judges - to weigh and balance competing social interests and development objectives. ${ }^{8}$

Notwithstanding, the transplant of a whole new legal culture to developing countries has proved to be a difficult task to accomplish, without mentioning that this could be seen as some sort of imperialist imposition on third world countries from the developed world. Moreover, even though the emergence of human rights and a new focus on formal rights had lead human rights advocates to assert formal rights across the developing world, "national judges in the third world remained largely passive in face of such claims".?

As this model of State interventionism started to wear out and many developing countries faced serious fiscal crises in the late 1970s, new ideas started to gain terrain from the 1980s onwards. Under the influence of the Washington Consensus, the emergence of neoliberal ideas brought to light a strong belief in markets as necessary and sufficient arenas to the development of economy. In this context, the "new institutional economy" grew in importance, based on two theoretical pillars: the weberian legacy ${ }^{10}$ and institutional approach.

Weber, by the end of the XIX century, had concluded that the best kind of law to support a capitalist economy would be one that provided investors with predictability. Thus, ideal law should be formal and rational, comprising general universal rules, and organized around a professional and autonomous bureaucracy, in order to guarantee the existence of companies with limited liability as well as the enforcement of contracts. ${ }^{11}$

The institutional approach to development, in turn, drew attention to the importance of institutions, the rules of the economic game, which reduce uncertainty and transaction costs by structuring incentives to agents' behavior. ${ }^{12}$ Even though institutions might be both formal (law) and informal (culture, traditions and ideologies), in the neoliberal context of the end of the XX century, the main ideas of institutionalist authors were simplistically interpreted, resulting in an institutional fetishism under the slogan "institutions matter". Institutions came to be seen mainly in a formal and under-humanized way, as if they were structures external to the markets.

Law, therefore, was responsible for creating markets and for ensuring a safe and predictable environment for investors. It assumed the task of imposing limits to the state's regulations and on the discretion

8 KENNEDY (2006), p. 112.

9 KENNEDY (2006), p. 123.

10 PISTOR \& MILHAUPT (2008)

11 TRUBEK (1972)

12 NORTH (1990) 
of public administrators, seen as the cause of economic distortions. The protection of private property, the incentives to competition and the reduction of transaction costs became the focus of developing countries.

Completely new legal regimes were necessary in order to build down import substitution regimes, privatize state-owned enterprises, establish financial institutions, and support new capital markets, thus supporting free markets, guaranteeing free trade and constraining the discretion of the State. The focus shifted from public to private law and the legal discourse switched from distributional and social concerns to the quest for formalization, elimination of corruption, fiscal discipline and economic efficiency. ${ }^{13}$

International institutions such as the World Bank started to support and finance institutional standardized reforms in several countries, in a "one size fits all" fashion, based upon the notion that the good law, well enforced, would result in good economic results. ${ }^{14}$ Legal reforms and legal transplants became ever more frequent, in pursuit of the integration of developing countries to the global economy. The main focus of such reforms was the judicial system as an essential institution for the protection of property rights and the enforcement of contracts.

Courts grew in significance as they gained powers of judicial review and began to challenge the decisions made by the Executive or the Legislative branches on the basis of protecting individual property rights, enforcing contracts and guaranteeing the predictability and stability of the business environment. At that moment, there was little or no room for discussing civil rights or the political role of law in the protection of minorities and of people living in extreme poverty. Judicial review was based upon a formalist approach to law along with a judicial policy analysis borrowed from neoliberal economics. ${ }^{15}$

By the mid 1990s, however, the bad results of the neoliberal program to the development of third world countries fueled criticism to this vision of Law and Development. Indeed, many countries that had adopted neoliberal policies went into economic crisis. This has lead to the conclusion that, although markets might be the main mechanism of efficient distribution of resources in a society, they are certainly incapable of creating, by themselves, the conditions for their success. Identifying market failures, scholars such as Stiglitz started to sustain the need for the state's moderate intervention. ${ }^{16}$

There is certain consensus that while the State should not be the main economic engine, it should neither be the neoliberal minimal State. It should rather be medium-sized State that acts as the economy's ally,

13 KENNEDY (2006), p.

14 PISTOR \& MILHAUPT (2008)

15 KENNEDY (2006), pp. 141-142.

16 TRUBEK (2010), pp. 5-7. 
oriented towards maintaining a social democratic market, integrated with the world economy. ${ }^{17}$

It is widely acknowledged, moreover, that the legal reforms and transplants, undertaken without due attention to the particularities of local institutions were not effective or created results considerably different from the expected. Thus arose the notion that reforms should be gradual, incremental and always context-specific. ${ }^{18}$

Since the end of the 1990s, therefore, the world seems to be experiencing the emergence of a third moment in the Law and Development movement, marked by the understanding that law must correct market failures and that legal reforms must be done with attention to local existing institutions. ${ }^{19}$ Law has remained, as in the two previous moments, an instrument of development policy and a vehicle for weighing and balancing complex policy analysis. In this new moment, however, "law has also become an end in itself" Law, human rights and the rule of law are no longer considered as development tools, but as development objectives, as part of the very definition of what development is.

Indeed, as will be explained subsequently, income and economic growth are now considered as only one of the many aspects of development. This has lead to an expansion in the concept of development: if before development meant economic growth, today it has incorporated other dimensions, such as those regarding human, social, political and legal development. ${ }^{21}$

As a result, development policy-making has currently started to encompass a new social agenda and has turned its attention to the implementation of legal institutions such as "elections, Courts, judicial review, and local human rights commissions and the legal framework for a robust "civil society" 22 . This more enhanced policy role for law has important effects on the judicial system, that is now able to play a more robust role in weighing acquired rights against justifications for development policies.

The extent to which judicial systems in developing countries actually make use of this new prerogative, the way they do it and the difference that a more active judicial system might make in the development outcomes of countries are questions that remain

17 KENNEDY (2006), p. 156.

18 In this regard, see EVANS (1995), on the idea of "embedded autonomy" and PRADO \& TREBILCOCK (2009), on the concept of "path dependence". For a more general view on the results of the institutional reform movement, see TAMANAHA (2010).

19 TRUBEK \& SANTOS (2006), pp.7-9.

20 KENNEDY (2006), p. 158.

21 In this regard, see SEN (2010)

22 KENNEDY (2006), p. 159. 
unanswered and to which the present article aims to contribute.

\section{DEVELOPMENT AND THE IMPORTANCE OF GOOD DEMOCRATIC INSTITUTIONS}

This article is grounded in a broad concept of development, typical of what has been referred to as the third moment of Law and Development. Thus, differently from the traditional view that asserts development as the achievement and maintenance of economical prosperity, here development shall be considered as the guarantee of individual liberties ${ }^{23}$ through good democracies ${ }^{24}$ which allow individuals to act as agents of change. ${ }^{25}$

Granting individual freedoms means reducing or abolishing the socioeconomic restraints imposed on individual's choices and, therefore, assures individuals autonomy to choose whether and how they will enjoy their rights. Accordingly, development includes the increase in levels of education and intellectual independence, which allow individuals to break free from societal restraints. ${ }^{26}$ In this sense, individuals shall be able not only to make their own choices, but to form their interests considering a larger scope of options.

This concept of development does not disregard the importance of economical growth for development, but qualifies it as being only one among the necessary means to achieving the objective of development, which is the expansion of individual capabilities. Indeed, the lack of resources restricts governmental capacity to promote social policies aimed at grating all individuals' equal capacity to freely enjoy their rights. Accordingly, the lack of a minimum income restricts individuals' capacity to choose whether and how to enjoy their rights, whereas the possession of a minimum income may potentially enlarge the enjoyment of those rights. ${ }^{27}$

However, despite the importance of economical prosperity, it should not be considered the aim of development. ${ }^{28}$ High productivity and income do not guarantee by themselves quality of life, equal distribution of wealth and the enjoyment of individual liberties. An example of this statement can be observed in the difference between

23 SEN (2004)

24 INGLEHART \& WELZEL (2005)

25 SEN (2004)

26 INGLEHART \& WELZEL (2005), p. 24.

27 An illustration of this assertion is the following situation: poverty recurrently deprives individuals from medical solutions to easily treatable diseases. Should all individuals possess a minimum income, they could choose whether or not to resort to medicine instead of being automatically condemned to suffer from the diseases consequences.

28 STIGLITZ (1998), p. 76-78. 
Brazilian GDP and HDI: while Brazil has the 7th higher GPD of the world ${ }^{29}$, it is ranked $85^{\text {th }}$ place in global HDI. ${ }^{30}{ }^{31}$ In other words, Brazil's economical prosperity does not guarantee that every person in the country is fully capable of exercising their freedoms. ${ }^{32}$

Therefore, this article does not ignore the importance of economical prosperity in achieving development, but assumes that it is not the only or main aspect which should be considered in measuring development. In this sense, the concept of development adopted is broader and aimed at guaranteeing ample individual freedom.

As previously mentioned, the guarantee of individual freedom means providing individuals the possibility to make their own choices without socioeconomic limitations and according to values they regard as important. Asides from its intrinsic importance, individual freedom is crucial because it not only enables individuals to shape their own lives, but also allows them to participate in social matters and influence collective outcomes ${ }^{33}$. Thus, individual freedoms are both means and ends of development. ${ }^{34}$

Concurrently, the achievement and maintenance of development depends on the existence of good democratic institutions, which are the only ones that can actually grant individuals equal capabilities to participate in public matters and to influence in policy drafting and implementation, as well to evaluate the legality and responsiveness of government actions. ${ }^{35}$ Amongst other factors, the quality of democratic institutions lies upon a competitive electoral system $^{36}$, transparent governmental affairs, rule of law $w^{37}$ and assured means of direct civic

29 Information obtained from the Human Development Report 2013 from the United Nations Development Program, accessible at http://www.pnud.org.br/arquivos/rdh-2013-resumo.pdf.

30 Information obtained from the International Monetary Fund website, accessible at http:// www.imf.org/external/pubs/ft/weo/2012/02/weodata/index.aspx.

31 India and South Africa are also good examples: while India has the $10^{\text {th }}$ higher GDP in the world, it is ranked $136^{\text {st }}$ place in global HDI; while South Africa has the $29^{\text {th }}$ higher GDP in the world, it is ranked $121^{\text {st }}$ place in global HDI.

32 According to research published by IBGE (Brazilian Institute of Geography and Statistics), $31 \%$ of Brazilian society has educational delays and $40 \%$ does not have access to water, sewage and electricity. Information obtained at http://www.ibge.gov.br/home/estatistica/populacao/ trabalhoerendimento/pnad2011/default_sintese.shtm

33 SEN (2004), pg. 13-25

34 SEN (2004), pg. 13-25

35 DIAMOND \& MORLINO (2005), p. xi.

36 In a good quality democracy, all political parties must be able to participate in a free, fair and regular electoral competition. Without such an electoral system, societies' interests cannot find true governmental representation. DIAMOND \& MORLINO (2005), pg. vii.

37 In this context, the concept of rule of law adopted is the same as endorsed by DIAMOND \& MORLINO, which consists in "under a rule of law all citizens are equal before law, which is fairly and consistently applied to all by an independent judiciary, and the laws themselves 
political participation.

Therefore, concerns with the quality of democracies go far beyond representation mechanisms and procedures. As a matter of fact, vertical accountability ${ }^{38}$ plays a central role in democracy because it grants civil society means to intervene in political actions and institutions, and diminishes the difficulties originated by the shift from direct to representative democracy. ${ }^{39}$ Because it is a government designed by society for society, citizens considered individually or collectively are the only true holders and evaluators of their interests. ${ }^{40}$

In this sense, designing and implementing democratic institutions is not sufficient per se. It is crucial for a good democracy that institutions be designed context-specific and, more importantly, considering mass culture. To be truly effective, democratic institutions need to stimulate society's participation, account with their trust and meet their expectations and values. Individual cooperation and submission to democratic institutions are directly related to their acquaintance with the rules and institutions which affect their lives ${ }^{41}$.

Therefore, considering that development is aimed at guaranteeing ample individual freedom and that it can solely be achieved with civic engagement and participation, a political system which institutionalizes mass culture and provides plural means of controlling power is crucial. In other words, democracies of good quality are the only known political systems capable of truly enabling the achievement and maintenance of development as outlined in this article.

Nevertheless, in some new democracies, which often present weaknesses in their democratic outcomes,${ }^{42}$ society has been losing faith in traditional representative institutions which are directly associated to the democratic performance, such as the executive and legislative branches. ${ }^{43}$ In this scenario, the Judiciary has been assuming

are clear, publicly known, universal, stable, and nonretroactive". DIAMOND \& MORLINO (2005), pg. vii.

38 Accountability is the possibility of elected governmental representatives be held responsible for their political decisions. There are two forms of accountability: vertical and horizontal. Vertical accountability is carried out by voters in elections when choosing who will be the subsequent governor. In other words, citizens exercise vertical accountability when they do not reelect a politician who did not meet societies' expectations during exercise of mandate, or when they reelect a politician which met societies' expectations during exercise of mandate. Horizontal accountability, on the other hand, is carried out by other governmental actors which have constitutional or legal authority to do so. DIAMOND \& MORLINO (2005), pg. xv-xvii.

39 DIAMOND \& MORLINO (2005), pg. xiii.

40 DIAMOND \& MORLINO (2005), pg. xiii.

41 MOISÉS (2010), p. 4.

42 Existence of corruption and lack of full enjoyment of individual fundamental rights are examples of weaknesses in democratic outcomes.

43 MOISÉS (2010) 
an important role in promoting rule of law and accountability of the elected representatives, ultimately aiding government in regaining societal trust and cooperation. As will be subsequently shown, this is a new role assumed by the judiciary and that, despite its notable benefits, has suffered severe criticism.

\section{Judging POLICY ANd ESCR In THE DEVeloping WorLd}

With the wide recognition that individual and social rights, the rule of law and good democratic institutions are relevant for the achievement of development, the judicial system is becoming an increasingly relevant political player. Judges and Courts now share a broader foundation to constrain the discretion of the Executive and of the Legislative in their policy decisions.

By questioning complex policy decisions that involve the allocation of scarce resources the judicial system influences policy drafting and implementation. It also assumes a relevant position because it has become a participative arena trough which individuals may hold accountable those who are fulfilling governmental representation.

Specially in developing countries, where governmental representative organs are not always responsive to society's wills and have lost their trust ${ }^{44}$, judges have recurrently been called upon to intervene in political matters, recognizing rights, intervening, designing and implementing public policy. ${ }^{45}$

Thus, the Judiciary system has assumed a double role in development: firstly, it has become an additional political arena where rights may be conquered and guaranteed, and secondly, it is one of the only governmental organisms that still counts with considerable societal trust. In this sense, judges not only have acted in removing barriers imposed on the enjoyment of individual liberties, but also aid government in recovering societies' trust and desire to intervene positively in public matters.

This has been done through judicial adjudication of ESCR's, which aims not only at establishing liabilities and repairing damages, but also at promoting institutional change in order to avoid future disrespect of rights and damages. In the past decades, the number of lawsuits on this behalf has greatly increased in many countries. ${ }^{46}$

44 VERÍSSIMO (2006), pp. 67-68.

45 LIMA LOPES (2006), pp. 190-191.

46 For examples, see GLOPEN, Siri; SKAAR, Elin \& GARGARELLA, Roberto. "Democratization and the Judiciary: The Accountability Function of Courts in new democarcies". London: Frank Cass Publishers, 2005; SABEL, Charles F. \& SIMON, William H. "Destabilization rights: How public law litigation succeeds". 117 Harvard Law Reviw. 1016 2003-2004; and GLOPPEN, SIRI. "Social Rights Litigation as Transformation: South African 
The judicial adjudication of ESCR's has been criticized in many different ways. Most commonly, it has been questioned on the grounds of the legitimacy of the judicial system to decide on the design and implementation of public policy, since its officials are not elected by the popular vote in democratically held elections. According to this view, this pro-active posture from the judicial system violates the postulate of the separation of powers and encroaches the powers of the Executive and the Legislative spheres in its political decisions. ${ }^{47}$

Unlike that, however, judicial action in related to ESCR may be considered a democratically legitimate mechanism that has the potential to prevent other governmental branches' inertia in guaranteeing and implementing constitutional rights, by giving voice to minorities or marginalized sectors of society that haven't been able to promote responsiveness in the traditional elected institutions. ${ }^{48}$ The rise in the number of these lawsuits shows that social participation in the formulation and implementation of public policy has been intensified. ${ }^{49}$

ESCR litigation has also been subject to the so called the neoinstitutional claim: since the judicial system is an important guarantor of predictability and property rights, judicial interference in policy matters would raise transaction costs, which would repel investors and interfere with economic development. ${ }^{50}$ The idea according to which judicial decisions should follow economic efficiency criteria, however, is quite problematic. For one, it is not an objective criterion; thus, it seems impossible to develop an adequate method of decision-making, able to guarantee that all variables are weighed and that would not allow for judges to include ideological variables into the equation. Secondly, adopting economic efficiency as the main criterion for judicial decisions would mean to ignore other relevant variables such as the existing inequalities between individuals. ${ }^{51}$

Lastly, one frequently pointed and problematic issue regarding ESCR litigation relates to the institutional capacity of the judicial system to deal with the complexity of making policy decisions. Because the judicial system has been originally designed to solve private bilateral conflicts, its structure and procedures would not be appropriate to solve issues involving distributive justice, scarce public resource allocation, and with potential collective impacts. It is argued therefore that success in ESCR adjudication depends on a radical change in the traditional model of adjudication currently used by the judiciary, with the inclusion

Perspectives". Bergen, Chr. Michelsen Institute, 2005.

47 BADIN (2011), pp. 36-44.

48 SUNSTEIN(1988), UNGER(1996), SABEL(2003-2004) and FISSCourt(1979-1980).

49 BADIN (2011), pp. 36-44.

50 VERÍSSIMO (2006), pp. 76-77.

51 BADIN, (2011), p. 33. 
of more collective values. For that reason, at least in Brazil, propositions to modify the adjudicative process have been discussed.

It is important to highlight that this article does not advocate an inconsequent judicial activism. Indeed, it is imperative to consider the potentially irrational results judicial activism may produce. Empirical research on social rights litigation in Brazil shows that the judicial interference in public policy matters can produce irrational effects on public policy itself, as well as on public budget allocation. Also, especially because of individualistic litigation of ECSR and of the rather unequal access to justice, litigation tends to favor those who, for financial reasons, need the judicial remedy less, therefore not promoting effective social change. ${ }^{52}$

In spite of all criticism, however, judicial adjudication of ESCR's is presently a growing and probably irreversible phenomenon. So far it has eventually enabled the recognition and enforcement of rights and systemic change. The public debate it produces has itself a great positive potential. Hence, while the debate may focus on the strengths and weaknesses of the judicial system, it seems more productive to look at the problem from a different perspective.

Indeed, this approach does not allow for the comparison between the judiciary and the many other institutions that, in practice, are also making policy decisions and electing the means by which the constitutional ends should be reached. ${ }^{53}$ Judges and Courts compete with public administrators, legislators as well as with market participants for decision-making. Each of these arenas has procedural and structural singularities that create different environments for decision-making in terms of symbolism, ability, political capital and timing.

This allows for the replacement of an analysis centered in the problems of the judicial adjudication of ESCRs for an analysis based on the concept of institutional dialogue. Thus, the question is no longer "is the judicial system able to take political decisions?", but "how, in specific cases, the different branches interact to the historical construction of arguments in favor of certain political decision?".

The idea of an institutional dialogue, supported by Mendes ${ }^{54}$, depends on overcoming the rigid interpretation of the separation of powers according to which the legislative branch create laws, the executive branch applies them and the judiciary judges conflicts according to them. This rigid approach to the system of checks and balances, worried with determining which branch should have the last word on each issue, is anachronistic and insufficient to describe a world where instead of a linear and finite process there is a permanent and

52 SILVA \& TERRAZAS (2011), pp. 825-853; WANG (2008).

53 BADIN (2011), p. 52.

54 MENDES (2011) 
cyclical political tension - for example: the fulfillment of a judicial decision depends on the executive's political will; and even after a judicial decision solves a concrete dispute, legislative might respond to the judicial understanding by altering the laws.

Hence, the design and implementation of public policies emerges from a more intricate, dialectical and permanent interaction of the different governmental branches, which dispute for political force and exchange arguments. The collective process of decision-making derives from a circular mechanism in which political and deliberative tensions influence each other mutually and in which there is no last word on any issue. ${ }^{55}$

It is important to notice that, while research points to the fact that currently there is more room for a more pro-active judicial system, the elucidation about whether Courts and judges actually do intervene in policy matters, the quality with which they do it and the social consequences of that pro-active posture depend largely on specific empirical studies.

\section{The JUdicial ADJUdiCATION OF ESCR IN A COMPaRATIVE PERSPECTIVE: BraZIL, INDIA AND SOUTH AFrica}

In an attempt to stimulate the subject herein addressed, this section will develop a comparative study on judicial adjudication of ESCR undertaken in Brazil, India and South Africa, and subsequently will carry out a brief analysis on food security policies implemented in these countries.

The comparative study shall be conducted according to a functionalist methodology and the aim will be to compare judicial adjudication of ESCR undertaken in Brazil, India and South Africa with respect to what kind of conflicts involving ESCR are addressed before national Courts and what are their outcomes. ${ }^{56}$ Therefore, judicial adjudication of ESCR in Brazil, India and South Africa will be primarily contextualized, that is, their origin and constitutional grounds will be explained, and in the sequence they will be discussed considering how they have been practiced. The policy analysis in turn, will briefly describe the background and development of food security policies carried out in each of the three countries with the aim of identifying strengths and weaknesses of the different governmental branches when formulating and implementing public policies.

The choice of developing a comparative study with Brazil, India and South Africa took into consideration three main aspects: firstly,

55 MENDES (2011)

56 MICHAELS, Ralf, "The Functional Method of Comparative Law” (2005). Duke Law School Faculty Scholarship Series. Paper 26, p. 5. 
the three countries chosen are members of the BRICS, international cooperation group formed by economically strong developing countries, and this comparison may contribute for self-understanding and deepening of their cooperation relationship; secondly, these countries possess different cultural and political backgrounds, which favors the encounter of different outcomes from the judicial adjudication of ESCR; and lastly, the judicial adjudication of ESCR carried out in these countries is widely known by scholars who study judicial systems.

\subsection{Judicial adjudication of ESCR in Brazil}

Brazil's Federal Constitution came into force in October of 1988 as a result of the transition to democracy from a military dictatorship that had began in 1964. This new political document, responsible for designing the State and recognizing individual and social rights, had birth in a moment when social demands were urging against approximately 20 years of brutal censorship and offense of individual and collective rights. At the moment, translating demands from all social movements into the constitution text was a symbolical and legitimizing act. ${ }^{57}$

Many different interests and social demands were included in the constitutional text, which ended up with $30,5 \%$ of its norms aimed at designing public policy. ${ }^{58}$ It is ${ }^{59}$ the constitution with the highest percentage of public policy norms in the world. ${ }^{60}$ One of the main consequences of this constitutionalisation ${ }^{61}$ of rights and public policy is that it encourages excessive judicial adjudication since the Federal Constitution of 1988 grants broad access to the judiciary whenever rights are being violated or have not been ensured by the government; and given the disbelief of Brazilian society in the legislative and executive branches as protectors and promoters of constitutional rights.

Therefore, Brazilian judiciary is constantly sought to solve conflicts related to the substantial constitutionalisation of rights and

57 MENDES (2005), p. 452.

58 Two Brazilian Political Scientists, Rogério Arantes and Cláudio Couto, classified constitutional rules as policy and polity. According to their classification, polity rules (i) define the concept of State and Nation; (ii) declare individual and political rights; (iii) define the "rules of the game"; and (iv) declare material rights aimed at achieving well being and equality. Policy rules, on the other hand, design public policy. ARANTES \& COUTO (2009), pp. 17-51.

59 According to Arantes e Couto, from 1988 to 2008 Brazil's Federal Constitution was amended almost 40 times, growing $28 \%$ from its original size, being $70 \%$ of this growth public policy norms. 60 The second runner up in percentage of public policy in its content is Mexico's 1917 Constitution, with 17\% public policy norms. ARANTES \& COUTO (2010), p. 554.

61 According to ARANTES e COUTO, the term "constitutionalisation" implies that rights and/ or public policy are being placed in the constitution and, therefore, are acquiring constitutional stats and protection. 
public policy and to the consequent recurrent amendment of the constitution. Indeed, because of the Courts, in special the Federal Supreme Court, constant fearless practice of Judicial Review, the judicial System has assumed central role in the national political arena.

Because the judicial review system in Brazil combines the concrete and diffuse system practiced in the United States of America with the abstract and concentrated system adopted by the Federal Republic of Germany, any judge may declare the unconstitutionality of federal, state or municipal laws and decrees while sentencing concrete disputes, and the Federal Supreme Court (STF) may analyze the constitutionality of federal and state laws and decrees which are abstractly challenged by persons or organizations authorized to do so ${ }^{62}$.

This mixed judicial review system combined with the broad judicial autonomy and the lack of mechanisms capable of bonding judicial decisions to higher Courts' precedents ${ }^{63}$ allows judges to render decisions according to their personal preferences. Consequently, decision making regarding ESCR is widely disperse and contributes for unequal responses to similar cases ${ }^{64}$ In addition, a research carried out by Silva and Terrazas ${ }^{65}$ demonstrates that judicial decisions might benefit individuals who posses wealth above average due to a considerable disparity in access to the judiciary.

Therefore, even though Brazilian judges have been willing to promote judicial review, outcomes of judicial adjudication of ESCR have produced contradictory results, especially due to scarce access to the judiciary and lack of equality in decision making.

\subsection{Judicial adjudication of ESCR in India}

India is well known for its judicial effectuation of constitutionally guaranteed fundamental rights ${ }^{66}$. Indeed, as occurs in Brazil, the

62 The topic 3.2. has been written considering the Federal Constitution of Brazil, the Laws 9.868/99 and 9882/99, and the following articles: MENDES, Gilmar Ferreira. Controle de Constitucionalidade: uma análise das Leis 9868/99 e 9882/99. Revista Diálogo Jurídico, n. 11, fevereiro/2002, ROSENN, Keith S. Judicial Review in Brazil: Developments under the 1988 Constitution. 7 Sw. J. L. \& Trade Am. 2912000 and MENDES, Gilmar Ferreira. O Controle da Constitucionalidade no Brasil. Available at: http://webapp.pucrs.br/pagdisc/83000/Controle de_Const.\%20Gilmar\%20Mendes.pdf

63 TAYLOR (2008).

64 WATANABE (2006)

65 SILVA \& TERRAZAS (2011)

66 Judicial Adjudication of ESCR in India is widely known as Public Interest Litigation (PIL). However, as the term PIL has multiple meanings, this article chose to refer specifically to judicial adjudication of Economical, Social and Cultural Rights. In Brazil, for example, the term PIL may be used for litigation involving collectivities, governmental bodies and/or ESCR; in India, on the other hand, PIL refers solely to ESCR litigation. 
constitutional framework considering the recognition of fundamental rights and the outline of the Judiciary Systems' competences summed up with the social distrust in the representative governmental branches has stimulated an energetic practice of judicial activism by Courts of India ${ }^{67}$.

The Constitution of India was edited in 1947 as a result of the countries' conquest of independence from Britain and was aimed at establishing a "sovereign socialist secular democratic republic". In order to achieve this goal, the constitution recognized that all citizens should enjoy fundamental rights, which would be protected by an independent judicial system. ${ }^{68}$ This scenario has granted Indian judiciary, specially the Supreme Court, great power to influence in policy drafting and implementation, to hold accountable governmental officials and even to participate in law-making ${ }^{69}$.

Since the first cases of ESCR litigation in the 1970s, its practice has changed considerably until the current days. Initially ESCR litigation was usually filed by benevolent individuals in favor of underprivileged people against action or omission from the representative branches of government which had violated constitutional fundamental rights. At that time, judiciaries' response consisted in recognizing rights and holding government accountable for violating such rights. ${ }^{70} \mathrm{~A}$ second moment of judicial adjudication of ESCR in India started in the 1990s and was aimed at protecting a broader scope of rights. ${ }^{71}$ These lawsuits were usually filed by specialized NGOs and lawyers against defendants that were no longer exclusively governmental organs or representatives, but also private parties. Despite the considerable increase in the number of lawsuits filed, judges did not feel intimidated and were fearless in rendering decisions considering political matters. ${ }^{72}$ Finally, presently ESCR litigation is filed by any person and destined to protect an even greater scope of rights. The number of lawsuits has increased significantly, leaving judges overwhelmed with the workload and the lack of supporting judicial infrastructure. ${ }^{73}$

Judicial adjudication of ESCR in India has performed an important role in achieving social justice. Due to the flexible procedures designed by the Supreme Court for cases involving public interest,

67 RAJAMANI (2007), p. 294; DEVA (2009), p. 30.

68 DEVA (2009), p. 21.

69 RAJAMANI (2007), p. 294.

70 DEVA (2009), p. 27.

71 The second moment of LIP in India aimed at protecting fundamental rights, but was also destined to seek, inter alia, the end of sexual harassment at workplace, good governance, relocation of industries and the general accountability of the government. DEVA (2009), p. 28.

72 DEVA (2009), p. 27-28.

73 DEVA (2009), p. 28-33. 
underprivileged people have been able to access the judiciary system and see their rights be recognized and effectuated. Moreover, judicial adjudication of ESCR has acted in promoting accountability, in inducing parliament to overcome legislative vacuums, and in recognizing rights such as education, health and pollution-free environment. ${ }^{74}$ Not only did it aid in recognizing rights or promoting efficiency and transparency in governmental affairs, but it also aided the judiciary system in regaining societal trust. ${ }^{75}$

However, judicial adjudication of ESCR in India has also caused some inconvenient. Problems are related to the workload, lack of judicial infrastructure to handle all lawsuits relating to ESCR, deficiency in social participation and lack of knowledge to solve specific technical and political matters. Furthermore, the flexibility and ample access to judiciary has stimulated the misuse of judicial adjudication of ESCR for private instead of public benefit. ${ }^{76}$

Despite the troubles caused by ESCR litigation in India, academics and Courts continue to endorse this practice due to its abilitity of promoting social justice. Solutions to the pointed problems have been debated and some measures, such as the imposition of fines to hazardous litigants, have been implemented. ${ }^{77}$

As seen, judicial activism is widely practiced both in Brazil and in India, in spite their different cultures and political backgrounds. Not only are their judiciary system active in recognizing and effectuating rights, but they are currently seen by the people as a locus for discussing political matters. However, the different constitutional background of both countries has led to different types of responses from the Judicial System to political matters: even though Brazilian Courts are proactive in recognizing and guaranteeing rights, they are less eager than Indian Courts in flexibilizing and creating new procedural and substantive norms.

Accordingly, judicial adjudication of ESCR in both countries meet difficulties. While in India the ease of accessing and obtaining positive responses from Courts with respect to ESCR has stimulated an avalanche of lawsuits, the decentralization of the judicial protection of ESCR in Brazil stimulates these rights be adjudicated individually, receiving unequal responses.

\subsection{Judicial adjudication of ESCR in South Africa}

South African judicial adjudication of ESCR, on the other hand,

74 RAJAMANI (2007); DEVA (2009)

75 DEVA (2009), p. 32.

76 DEVA (2009), p. 35.

77 DEVA (2009), p. 37. 
is well known because it combines a constitution which amply recognizes rights with a timid judicial intervention in protecting these rights.

The current South African Constitution is fairly new: it was first drafted in 1993 by a democratically elected Constitutional Assembly and came into force in 1996 after being certified by the new South African Constitutional Court. In its origins is the democratization process that followed the end of the apartheid system and, therefore, was aimed at abolishing parliamentary sovereignty and social discrimination and inequality ${ }^{78}$ through the separation of powers and the guarantee of ESCR.

Not only did South African Constitution recognize an ample list of ESCR, it expressly stated that Courts might declare rights and grant appropriate reliefs when rights are being violated. ${ }^{79}$ Moreover, the Constitution establishes guidelines that must be followed by the Courts when interpreting laws and the Constitution, consistent in the promotion of "values that underline an open and democratic society based on human dignity, equality and freedom" and in consideration of relevant international norms. ${ }^{80}$ However, despite having a forward Bill of Rights, South African recent authoritarian and segregation experience with Apartheid still haunts Courts inducing them to intervene timidly in the protection of ESCR with fear of trespassing the border of separation of powers. ${ }^{81}$ The Supreme Court of South Africa has judged few lawsuits involving ESCR and has responded with ambivalent solutions.

In the first ESCR lawsuit filed before South African Supreme Court, Soobramoney vs. Minister of Health, regarding the right to emergency health services, the Court declared that conflicts regarding budgetary matters were not amongst the Judiciaries' competences and, therefore, should be dealt with by the executive branch ${ }^{82}$. Three years later the Supreme Court faced another ESCR lawsuit, Republic of South Africa vs. Grootboom, concerning the right to housing. Differently from the previous ESCR case, despite not directly enforcing the parties' rights, the Supreme Court declared government was obliged to establish policy that made universal enjoyment of such right effective in all national territory. ${ }^{83}$ Even though Grootboom was the milestone for the judicial active protection of ESCR in South Africa, the case Minister of Health and Others vs. Treatment Action Campaign and Others (TAC) represented an even greater step in that direction. In this opportunity the Supreme Court declared State was required to, when

78 EBADOLAHI (2008), pp. 1565-1566; GLOPEN (2005), pp. 8-9.

79 View section 38 of South African Constitution. EBADOLAHI (2008), p. 1566.

80 EBADOLAHI (2008), p. 1566; KENDE (2003), p. 141.

81 See EBADOLAHI (2008), GLOPEN (2005), KENDE (2003)

82 EBADOLAHI (2008), pp. 1580-1581; GLOPEN (2005), p. 10; KENDE (2003), pp. 145-146.

83 EBADOLAHI (2008), pp. 1582-1583; GLOPEN (2005), pp. 10-11. 
feasible, supply anti-retroviral drug to HIV-positive pregnant woman and their newborn child. Therefore, not only did the Supreme Court declare the justiciability of the right, but enforced it ${ }^{84}$.

Despite the development undertaken in ESCR judicial protection in South Africa, Courts are still reluctant to enforce individual and collective constitutional rights due to their fear of disregarding the principle of separation of powers. As Siri Glopen points out, the responsibility for this ambivalent behavior from South African Courts cannot be imposed on the legal system because Courts from Countries with less permissive constitutions, such as the Indian Supreme Court, are more proactive in protecting ESCR ${ }^{85}$ The answer may reside in the Countries' recent apartheid experience or on its judges' background.

As can be noticed in all three countries analyzed, the wide constitutionalization of rights combined with the lack of responsiveness or distrust in the representative governmental branches has stimulated citizens to find solution of conflicts involving ESCR in the Judicial System. However, judges in South Africa are more wary than Indian and Brazilian judges in protecting ESCR when it requires entering the grey zone of the separation of powers.

There is noticeably no right answer when it comes to the limit of judicial intervention in ESCR protection because all of the three described systems possess positive and negative impacts. While in India and Brazil there are more means for effectively guaranteeing, protecting and effectuating rights, in South Africa the difficulties caused by judicial intervention in political matters are less noticeable.

\subsection{Comparative study on food security policy}

This section will briefly analyze the implementation of food security policy in Brazil, India and South Africa. Considering that the scope of this study is only to comparatively analyze how different governmental branches from these countries influenced the design and implementation of a specific public policy, the case description shall be done briefly. ${ }^{86}$

The choice for studying food security policy took into consideration two main reasons: firstly, the access to sufficient food capable of assuring a healthy life is a basic right without which one cannot fully exercise its capabilities; and secondly, all of the analyzed countries in this article have implemented food security policies and have done it in particularly different ways.

84 GLOPEN (2005), p. 11.

85 GLOPEN (2005), p. 13.

86 For more details about food safety policy implemented in Brazil, India and South Africa, see SOUZA \& CHMIELEWSKA (2011) 
All of these three countries have recognized the right to adequate food by signing and ratifying the International Convenant on Economic, Social and Cultural Rights (ICESCR). At the national level, South Africa and Brazil have expressly declared the right to adequate food in the constitution. India, in turn, had the right declared by the Supreme Court as an interpretation of the article 21 of the Constitution, which guarantees the right to life and personal liberty ${ }^{87}$.

In India the Judiciary has played a leading role in designing and implementing the Food Security Policy. The unreasonable levels of hunger and malnutrition tolerated by the government led individuals to request the Supreme Court to recognize the universal right to sufficient food and the Court, in accordance to its previous decisions regarding ESCR, declared that every individual has the right to sufficient food. Accordingly, to guarantee enforcement of its decision, the Supreme Court appointed independent commissioners that would be responsible for measuring the levels of hunger and for monitoring governmental actions towards the fulfillment of the right to sufficient food. However the reports produced by the commissioners have been employed by the Supreme Court in further decisions rendered on the right to sufficient food, they are often incomplete due to the refusal of some State governments to answer the commissioners. ${ }^{88}$

This scenario has led Food Security Policies in India to be highly decentralized and uncoordinated: the several policies which are designed and implemented by each State government are not related to a single centralized policy framework. There have been some attempts to promote dialogue and coordination among the different State implemented food security policies, but a structured and coherent dialog has not yet happened ${ }^{89}$.

In South Africa, the right to food was recognized by the 1996 Constitution and was uniformly tackled by the National Integrated Food Security Strategy (IFSS), which was implemented in 2002 with the scope of harmonizing all the existent and disperse food-security programmes. IFSS is a multi-sector policy which provides a general structure for governmental intervention in safety nets and food emergencies; household food production and trading; nutrition and food safety; income opportunities; analysis and information systems; stakeholder dialogue; and capacity building ${ }^{90}$. Accordingly, IFSS possesses a decentralized structure which involves all governmental tiers and civil society. Despite the advantages inherent to multi-tier and multi-stakeholder policy strategies - such as the resort to multiple

87 SOUZA \& CHMIELEWSKA (2011), pp. 13-15.

88 SOUZA \& CHMIELEWSKA (2011), pp. 13-14.

89 SOUZA \& CHMIELEWSKA (2011), pp. 16.

90 SOUZA \& CHMIELEWSKA (2011), p. 6. 
solutions to tackle a multifaceted problem and the earshot monitoring of large scale programmes -, IFSS has been facing difficulties in coordinating the programme due to implementation problems, resource limitations, timid social participation and departmental rivalry ${ }^{91}$.

In Brazil food protection policy is outlined in laws pertaining to the Zero Hunger (Fome Zero) Programme, which was created in 2003 with the scope of acting in four areas: food access; coordination, mobilization and social control; income generation and strengthening of small agriculture. Along with Zero Hunger, in 2010 Brazilian government created the National Food and Nutritional Security Policy (PNSAN) which established the principles and objectives of governmental actions towards food security ${ }^{92}$. Both Zero Hunger and PNSAN account with multi-stakeholder coordination mechanisms which count with the participation of society and all three governmental tiers (federal government, state government and municipalities). The PNSAN has two main coordination bodies: the Interministerial Chamber on Food and Nutritional Security (CAISAN), which is composed by members of the executive branch, and the Counsel on Food and Nutritional Security (CONSEA), which is composed by governmental and civil society representatives. While CONSEA has the scope of discussing the main policy subjects involving programmes and budget, CAISAN analyzes the policy drafted by CONSEA for designing and implementing policy programmes. This system has allowed qualified social participation and the design of public policy bottom up, that is, context specific and according to true societal needs. However, Brazilian multi-tier and multi-stake holder has also been facing some problems due to the difficulty of guaranteeing that all governmental organs involved truly cooperate with the programmes designed ${ }^{93}$.

Therefore, the executive branches from Brazil and South Africa adopted a multi-tier and multi-stakeholder strategy to implement food security policies. A multi-tier policy is aimed at tacking a problem with multiple actions - eg. in food safety policy, it is possible to combine programmes such as conditional cash transfer and agricultural training for small producers - and a multi-stakeholder policy counts with multiple participants in drafting, implementing and monitoring the policy. If successfully implemented, these multi-tier and multistakeholder policies are hands down more promising than other policies. However, as has been felt in Brazil in South Africa, their coordination is challenging. Differently, in India, where the judicial Food Security Policy was designed and implemented by the Judiciary, the lack of political will to implement the decisions resulted in the existence of

91 SOUZA \& CHMIELEWSKA (2011), p. 6.

92 SOUZA \& CHMIELEWSKA (2011), p. 12.

93 SOUZA \& CHMIELEWSKA (2011), pp. 19-21. 
several decentralized and crumbled policies.

In this sense, some fruitful conclusions may be extracted from this brief description of the food security policy implemented in Brazil, India and South Africa. Initially, all cases analyzed indicate that the international pressure and the consequent constitutional recognition of rights promote significant pressure on government in guaranteeing that it be fully enjoyed by all individuals. Another conclusion that may be deduced from this description is that different cultural, social and economical contexts may require diverse policy solutions. In respect to the different branches participation in policy design and implementation, it is clear that the ideal arenas for this task are the executive and legislative branches. Despite the problems currently faced by Brazil and South Africa in Food Security Policy implementation and monitoring, their examples indicate that policies may be ideally implemented when they count with a plurality of solutions and actors.

On the other hand, the Indian example on food security policy makes it clear that when the representative governmental branches are silent or violate rights, the judiciary may intervene in recognizing and enforcing those rights. If Supreme Court had not recognized and enforced the right to sufficient food, the lack of political will in India to tackle hunger and malnutrition would have left individuals powerless and without means to enjoy the mentioned right. Nonetheless, Indian Food Security Policy would probably be more effectively implemented if there were a true dialog and participation between the Supreme Court and other government branches.

\section{Conclusion}

As has been seen, the judicial system has historically been assigned different roles in society. During the 1990s, neoliberal economic mainstream proposed that judges and courts should act to guarantee property rights and contracts, in order to promote development. More recently, however, mainly in developing countries, the judicial branch has become more active, guaranteeing individual and collective rights and, therefore, interfering in policy decisions regarding resource allocation which are taken by the Executive and Legislative branches.

This article has attempted to foster the debate over this new political role played by the judicial system and its possible importance in the promotion of development - considered to encompasses economic growth as well as the recognition of individual and social rights, the rule of law and good democratic institutions. Thus, this article has focused on the judicial adjudication of ESCR, as constitutionally recognized rights whose effectiveness depends largely upon the design and implementation of public policy. 
With the support of the comparative analysis of Brazil, India and South Africa, it has been shown that the judicial adjudication of ESCR may potentially terminate continuous violations of rights perpetrated by the representative branches of government. However, judicial intervention in public policy might be erratic, as shown by the example of the judicial adjudication of ESCR in both Brazil and India. It is also possible to conclude that the design and implementation of public policies should be designed in a dialectical and permanent interaction of the different governmental branches. Nevertheless, this coordination between governmental branches should not disregard the importance of public participation and new institutions must be context-specific and in accordance with society's values.

It is also clear that further empirical and comparative studies are essential in order to enlarge the understanding on the different institutional arrangements that are able to improve the political participation of the judicial system, making it able to improve democracy and to promote development.

\section{REFERENCES}

ARANTES, Rogério Bastos \& COUTO, Cláudio Gonçalves. Construção democrática e modelos de Constituição. Dados, Rio de Janeiro, v. 53, n. 3, 2010.

ARANTES, Rogério B. \& COUTO, Cláudio G. (2009) Uma Constituição Incomum, in M. A. R. Carvalho et alii (orgs.), A Constituição de 1988. Passado e Futuro. São Paulo, Hucitec/Anpocs.

BADIN, Arthur Sanchez. Controle judicial das politicas públicas: contribuição ao estudo do tema da judicialização da política pela abordagem da análise institucional comparada de Neil K. Komesar. Dissertação de mestrado apresentada à Faculdade de Direito da Universidade de São Paulo, 2011.

CAPPELLETTI, Mauro. Constitucionalismo moderno e o papel do poder judiciário na sociedade contemporânea. Revista de Processo, vol. 60, p. 110 a 116 Out / 1990.

DEVA, Surya. Public Interest Litigation in India: A Critical Review. Civil Justice Quarterly Issue 1, 2009.

DIAMOND, L. \& MORLINO, L. 2005. Assessing the quality of democracy. Baltimore: The Johns Hopkins Univ. Press, 2005.

EBADOLAHI, Mitra. Using structural interdicts and The South African human rights Commission to achieve judicial Enforcement of economic and Social rights in South Africa. 2008, New York University School of Law. 
EVANS, Peter. Embedded Autonomy - States and Industrial Transformation. New Jersey: Princeton Press, 1995.

FISS, Owen M. The supreme Court 1978 term - foreword: the forms of justice. 93 Harv. L. Rev. 1 1979-1980

GLOPPEN, SIRI. Social Rights Litigation as Transformation: South African Perspectives. Bergen, Chr. Michelsen Institute, 2005.

KENDE, Mark S. The South African Constitutional Court's Embrace of Socio-Economic Rights: A Comparative Perspective. 6 Chap. L. Rev. 1372003.

KENNEDY, David. The 'Rule of Law', Political Choices, and Development Common Sense. In TRUBEK \& SANTOS, The New Law and Development - a critical appraisal. New York: Cambridge University Press, 2006.

LIMA LOPES, José Reinaldo de. Brazilian courts and social rights: A case study revisited in: Roberto Gargarella, Pilar Domingo, and Theunis Roux. Courts and Social Transformation in New Democracies: An Institutional Voice for the Poor? 2006.

MENDES, Conrado Hübner. Deliberative Performance ofConstitutional Courts, tese de pós-Doutorado apresentada à Universidade de Edimburgo, 2011.

MENDES, Conrado Hubner. Judicial Review of Constitutional Amendments in the Brazilian Supreme Court. 17 Fla. J. Int'1 L. 4492005

MICHAELS, Ralf, The Functional Method of Comparative Law. Duke Law School Faculty Scholarship Series, 2005. Paper 26.

MOISÉS, José Álvaro. Democracia e Desconfiança de Instituições Democráticas, in Moisés, J.A. ET alli, Democracia e Confiança: Por que os Cidadãos Desconfiam das Instituições? São Paulo: EDUSP, 2010.

NORTH, Douglas. Institutions, Institutional Change and Economic Performance, Cambridge: Cambridge University Press, 1990.

PERELMAN, Jeremy. The Way Ahead? Access-to-Justice, Public Interest Lawyering, and the Right to Legal Aid in South Africa: The Nkuzi Case. 41 Stan. J Int'1 L. 357.

PISTOR, Katharina; MILHAULPT, Curtis. Law and Capitalism - what corporate crises reveal about legal systems and economic development around the world, Chicago: Chicago Press, 2008.

PRADO, Mariana Mota; TREBILCOCK, Michael. Path Dependence, Development and the Dynamics of Institutional Reforms. University of Toronto Law Journal, 59 (3), Summer 2009. 
Rights, Democracy and Development - Pereira Ferreira and Langenegger

RAJAMANI, Lavanya. Public interest environmental Litigation in India: exploring issues of access, participation, equity, effectiveness and sustainability. Journal of Environmental Law. (2007) Vol 19 No 3, 293-321.

SABEL, Charles F. \& SIMON, William H. Destabilization rights: How public law litigation succeeds. 117 Harvard Law Reviw. 1016 20032004.

SEN, Amartya. Desenvolvimento como liberdade. 4. ed. São Paulo: Companhia das Letras, 2010.

SEN, Amartya. What is the Role of Legal and Judicial Reform in the Development Process? in The World Bank Legal Review: Law, Equity, and Development, vol. 2. Washington: World Bank Legal. Rev, 2006.

SILVA, Virgílio Afonso da; TERRAZAS, Fernanda Vargas. Claiming the Right to Health in Brazilian Courts: The Exclusion of the Already Excluded? in: Law \& Social Inquiry 36, no. 4 (2011): 825-853.

SOUZA, Darana \& CHMIELEWSKA, Danuta. Public support to food security in India, Brazil and South Africa: Elements for a policy dialogue. International Policy Centre for Inclusive Growth (IPC-IG), United Nations Development Programme (UNDP): 2011. Available at: $<$ www.ipc-undp.org $>$.

SUNSTEIN, Cass R. Standing and the privatization of public law. 88 Colum. L. Rev. 14321988.

STIGLITZ, Joseph. Towards a New Paradigm for Development: Strategies, Policies, and Processes. Geneva: Prebish Lecture, UNCTAD, 1998.

TAMANAHA, Brian. O primado da sociedade e as falhas do Direito e Desenvolvimento. In Revista Direito GV, v. 6 (2010).

TAYLOR, Matthew M. Judging Policy: Courts and Policy Reform in Democratic Brazil. Stanford: Stanford University Press, 2008.

TRUBEK, David. Max Weber and the Rise of Capitalism, Wisconsin Law Review, 1972.

, Developmental States and the Legal Order: Towards a New Political Economy of Development and Law, in David Trubek, Law, State and Development in Latin America - Case Studies from Brazil, Colombia, Mexico and Venezuela (no prelo), 2012.

;SANTOS, Alvaro. Introduction: the Third Moment in Law and Development Theory and the Emergence of a New Critical Practice, in TRUBEK\&SANTOS, The New Law and Development - a critical appraisal. New York: Cambridge University Press, 2006. 
UNGER, Roberto Mangabeira. Legal Analysis as Institutional Imagination. 59 Mod. L. Rev. 11996.

VERÍSSIMO, Marcos Paulo. A judicialização dos conflitos de justiça distributiva no Brasil: o processo judicial no pós-1988, Tese de doutorado apresentada à Faculdade de Direito da USP, 2006.

WANG, Daniel Wei Liang. Escassez de recursos, custos dos direitos e reserva do possivel na jurisprudência do STF, in: Revista Direito GV, São Paulo, jul-dez. 2008.

WATANABE, Kazuo. Relação entre demanda coletiva e demandas individuais. Revista de Processo. São Paulo: RT, 2006, n.139. 